\title{
輸送機器の軽量化・低 $\mathrm{CO}_{2}$ 排出化に貢献する $\mathrm{CFRP}$ の役割
}

石川隆 司*

炭素繊維の工業生産が 1971 年に開始（株東レにて）さ れてから，半世紀弱が過ぎようとしている．この間，炭素 繊維強化プラスチック（CFRP）は，産業のいろいろな分 野に浸透・展開し, 徐々に産業の「コメ」となりつつある. その中でも, 高速移動することをミッションとしている輸 送機器は, CFRP の構造への応用の観点で, その普及展開 の衰引車の役割を果たして来ている。

本号では，鉄道・自動車・航空宇宙・船舶（舶用プロペ ラ）の分野に焦点を当て, 各部門の代表的有識者に, それ ぞれの立場から，現状と今後の展望についてご執筆いただ いた，各編の内容を要約することが，本欄の目的ではない と思料するので, 永年 CFRP の研究開発に従事してきた 立場から，それぞれの分野について，筆者の思うところを 開陳することとする。

鉄道車両分野であるが，以前から，車両の CFRP 化を 目指した研究開発が続けられてきた. しかし, 本格的な車 両構体の CFRP 化には至っていない.この理由として, 一つにはCFRP の高価格, もう一つは難燃性に関する要 求の厳しさがあると推量する. 後述する航空機においては, 難燃性の競争相手がアルミ合金であるので, CFRPはむし ろ優位に立つことは可能であるが，鉄道車両においては， 客室材料のライバルは鋼材であり，これを想定した難燃性 基準を満足するのは容易ではない. CFRP 母材としてフェ ノール樹脂が想定されているが, 成形の難しさが险路と なっている.このような中, その規制を受けない重要部品 として, 台車の CFRP 化が成功しているのは大進歩であ る. 鉄道車両の CFRP 化での今後の着目点は, 磁気浮上 高速鉄道構体であり, 研究が進んでいると推量するが, 難 燃性に関してどのように解決されるか注目したい。

自動車車体の CFRP 化については，筆者も自ら技術開 発に取り組んでおり, その困難さを体験している，F 1 マ シンあるいは超高級スポーツカーのようなものを除いた普 及量産車への CFRP 適用の関門は，まずコスト低下，そ れから大量生産に適した成形技術開発である．筆者の所属

\footnotetext{
* Ishikawa, Takashi

名古屋大学 ナショナルコンポジットセンター 特任教授

名古屋市千種区不老町（矛464-8603）

ishikawa@nuae.nagoya-u.ac.jp

2016.11. 9 受理
}

するナショナルコンポジットセンター（NCC）では，炭 素繊維と熱可塑樹脂を熔融・混練して押出し, 高速にプレ ス成形する LFT-D（Long Fiber Thermoplastic-Direct）を 用いた構造の成形技術の開発に取り組んでいる。いろいろ と技術課題はあるものの, 高荷重分担部ではない自動車構 造への CFRP 適用の重要なオプションであると確信して いる，一方，欧州，特にドイッでは，連続繊維 CF を用い た高圧 RTM（Resin Transfer Molding）による製品を適 用した自動車部材が商品化されており, 高負荷構造では, このような手法も重要な選択肢であろう。一つの技術的曙 光は，我が国における革新炭素繊維開発の成功であり，こ の生産が軌道に乗れば, 自動車への CFRP 適用の強い加 速力になると期待される.

最も CFRP の適用が浸透し, いまや構造の標準材料と なっている航空機分野では, 少なくとも大型の航空機では, 実用化は定着していると考える。ただ，最新のボーイング $777 \mathrm{X}$ ではコストの観点から，胴体がアルミ製に戻るなど の動きはあるものの, 成形の自動化技術開発が進めば，大 局的には CFRP化の流れの中にあると考える．また，現 状の航空機では CFRP 母材は熱硬化性のエポキシ樹脂中 心であるが，欧州では熱可塑性樹脂を母材とする CFRP の適用が増大してきた。これを加速する利点の一つは，接 合における融着（もしくは溶接）可能性であり, 今後の欧 州, 特に Fokker Aerostructures 社の動きに注目していき たい.また, 我が国においては, 成形・積層の自動化ロボッ 卜の開発の動きが悪く，この研究開発の加速にも大いに期 待したいところである.

最後の話題である船舶分野であるが，ボート・ヨット以 外の大型船殼全体の CFRP 化は，軍用の艦艇，特に掃海 艇など以外は現実的でないと考える。この中で，本号の筆 者が所属されるナカシマプロペラ(秼が取り組まれた舶用プ ロペラの CFRP 化は秀逸であり，鉄道車両における台車 への取り組みと大局的発想で似たところがある．この研究 開発の今後の進展に大いに期待したい.

このカラムの結言として, 最近, 筆者が講演の最後に述 べているフレーズを紹介したい. それは, 輸送機器の排出 する $\mathrm{CO}_{2}$ を軽減し，人類の未来に貢献する点で，「炭素繊 維と CFRP は人類の宝である」という決め言葉である. 